completed, so that publication will be discontinuous and will probably cover a period of about ten years. To subscribers parts will be sold at Kr. 1.00 per sheet, and the whole work is estimated to contain about 100-150 sheets. The two parts first to be published have been received-R. Spärck on "The Benthonic Animal Communities of the Coastal Waters", and E. Wesenberg-Lund on "Gephyrea". Both authors find that the fauna with which they deal consists mainly of an arctic and an arctic-boreal admixture, in which the latter predominates, and with which rare forms, such as the gephyrean Sipunculus norvegicus, represent a southern fauna which may have survived from a warmer period. In summing up the conclusions of his investigation, Spärck points out that the absence of a boreal shallow-water fauna seems to indicate that in postglacial time no land connexion can have existed between Iceland, the Faroes and the continent of Europe. But the fauna itself is by no means a sparse one, since in quantity it compares favourably with the fauna of the North Sea, which is generally considered to be very productive and is richer than the corresponding faunas of East Greenland and northern Russia. This relative wealth of bottom fauna may be a dominant factor in determining the presence of a fish population, which in turn has determined the importance of the fisheries in Iceland waters.

\section{Plants and the Dwelling-House}

Most people readily admit the value of cut blooms and growing plants for decoration of the home, but not all plants can make good growth in the somewhat trying conditions of the average dwelling-house. A recent publication of the Field Museum of Natural History, Chicago, is entitled "House Plants" (No. 20, 1937, 35 cents). It has been written by Mr. R. van Tress, and maintains the well-known practical out. look of this Museum's publications. Such well-tried subjects as the Aspidistra (here called, most appropriately, the 'cast iron plant'), the small conifer Araucaria excelsa, various geraniums, and the indiarubber plant (Ficus elastica) are known to all. The leaflet also shows that hybrid species of Hippeastrum, Hydrangea, Poinsettia, Begonia, Azalea, Primula sinensis, heliotrope, the African violet (Saintpaulia ionantha), the shrimp plant (Beloperone guttata) and many others, including the common English ivy, are suitable for domestic conditions. They give greater and more varied beauty than the better-known species. Many illustrations enrich the leaflet, and there would seem to be no reason why the plants mentioned therein should not succeed in Great Britain as well as in the United States.

\section{Supraconductivity}

THE issue of the Journal of the Washington Academy of Sciences of June 15 contains the address of the retiring president of the Academy, Dr. F. B. Silsbee, of the Bureau of Standards, delivered in January. It extends to twenty pages, and deals with the additions which have been made during the last two or three years to our knowledge of the electrical properties of metals at very low temperatures. References are given to previous summaries up to 1935 and to nearly thirty memoirs on the subject which have been published since, most of them in 1936. The original description of a supraconductor as one in which the resistivity is zero is beginning to be replaced by the newer one that the magnetic induction is zero and that any current which flows in it is confined to an excessively thin layer at its surface. The abruptness of the change of conductivity as the temperature is lowered has been investigated, and in the case of tantalum has been expressed by means of the error function. The paradox of how a magnetic field which cannot penetrate a supraconductor can still affect its conductivity is still unsolved, and the reasons for the decrease of heat conductivity and increase of specific heat in the supraconducting state have still to be determined.

\section{Philadelphia Academy of Natural Sciences}

THrs year the Academy celebrates its one hundred and twenty-fifth anniversary, and the opportunity has been taken of relating to friends and members in a special report the work accomplished during the past year. The title chosen for the report is "Discovery" (which unfortunately duplicates the name of a well-known British scientific periodical). The year was marked by the announcement of an ambitious programme which included the strengthening of the scientific work of the Academy, the inauguration of an Education Department which would correlate the work of the Academy with the public and private school system in Philadelphia, the erection of modern educational exhibits, and the re-establishment of the Department of Geology and Palæontology. For the support of the educational programme over a fiveyear demonstration period a sum of 374,915 dollars was required, and the response to the end of 1936 reached the fine total of 241,135 dollars. Already important steps have been taken towards the accomplishment of the programme, and we note with satisfaction that the first step was to restore the reductions which had been made during the period of stress in the salaries of the staff. We join with the Academy in lamenting the death on January 22 of its president, Mr. Effingham B. Morris, who since his election to the presidency in 1928 has been the leader and stimulus in all phases of the Academy's work for science and for the community.

\section{Peace Movements}

The "Peace Year Book, 1937" (London : National Peace Council. 2s.) contains a good deal of useful information on international affairs and should prove a reliable book of reference on the peace movement throughout the world. It includes directories of peace organizations in Great Britain, of national organizations, Anglo-foreign societies and local peace organizations as well as peace and kindred organizations abroad. The appendixes include the text of the Covenant of the League of Nations, a bibliography of books and pamphlets, notes on the reform of the League, the Mandates System, an analysis of the 